〔はじめに〕聴覚障害者の語音異聴を分析する目的で, 前回の本学会で日本語子音の異聴 特性と題して, 語音地図の作成方法と結果, ならびに聴覚障害者への応用方法の一部を発 表した。ととで語音地困と呼称しているのは, 聴力正常者を用いて日本語単音節 67 語相互 の聴覚心理的類似性を求め, その類似度を多次元尺度構成法 SMACOF t用いて, $1 \sim 5$ 次 元の空間に各単音節の相互関係として表現したグラフのてとである。今回は, 前回の基礎 的な研究を発展させ，臨床応用への可能性を追求した。すなわち，語音聴力検査で得られ た聴覚障害者の異聴のデータをての地図上に表現するためのマイクロコンピュータシステ ムを作成した。そしててのシステムを用いて, 語音地図上に聴覚障害者の異聴の内容を表 現した異聴地図を作成した。

〔マイクロコンピュータシステムの作成〕図1亿マイクロコンピュータシステムの概略存 示す。入力は, 語音弁別能力検査で聴覚障害者が誤答した語音と, どのような語音に異聴 したかを示す反応語音である。データベースには, 聴力正常者を用いて作成された日本語 単音節 67 語相互の聴覚心理的類縁関係を示す語音地図と, 音節核の母音別に求めた単音節 の類縁関係を示す語音地四が入っている。入力をすると, 聴覚障害者が誤答した語音を起 点とし，反応語音を終点とするべクトルがディスプレイ上に表示されるようになっている。 ディスプレイは, 座標, 文字, ベクトルを異なった色で表示できるようにカラーディスプ レイを用いた。また，プリンタを用いて資料を保存できるようにした。なお，単音節の表 示は音訓式のローマ字とし, ベクトルは一○の記号で表わし, ○印がついている方を終 点とした。

〔症例〕本システムの応用例として感音難聴例を提示する。純音オージオグラムは, 高音 急墜型で, 急墜開始周波数は $500 \mathrm{~Hz}$ 付近である。本症例に対し, 語音地図作成に用いたの と同じ 67 語の音声資料を用いて語音弁別能力を測定したとてろ, 最高明瞭度は $32.8 \%$ であ つた。ての検査デー夕を本システムを用いて分析したのが，図 $2 \sim$ 図 4 である。今回は， 分析方法を示す事を目的としているので，簡単にするために，作成した $1 \sim 5$ 次元の語音 地四のうち2次元の語音地図上に異聴を表示するととにした。図2 亿67語全体の異聴地図 を示した。ての図から，異なる音節核を持つ語音間にかなり多くの異聴が生じているてと がわかる。特に, 音節核が / u /と/ i / 語音相互飞著明な異聴傾向が認められる。ま た，音節核が/e/と/。/の間にも異聴傾向があるが，てれは主として $/ \mathrm{o} /$ から $/ \mathrm{e} /$ への異聴が起てっているためである。音節核が異なる語音へ異聴する場合, その $2 / 3$ は先行 子音が同一の語音へ異聴が生じていた。図2亿よって示されるもう一つの傾向は, 音節核 が異なる語音間より, 同一の音節核内での異聴が非常に多いととである。そとで, 同一の 音節核内の異聴を詳しく検討するために，音節核別の異聴地図を作成した。こてでは，

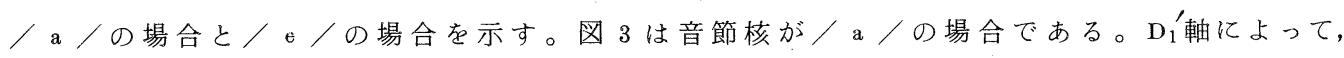
無声子音群と有声子音群に分かれている。本症例では, 主として有声子音群に異聴が生じ ており, また, 有声子音と無声子音間の異聴はまったく認められない。てれに対し, 図4 に示した音節核がノ $/$ e / 場合は, 有声子音, 無声子音の両方に異聴が生じ, 有声, 無声 
間の異聴も生じている。図4 中-----で示した補助線の間に有声子音と母音が配置されている。 [まとめ〕今回は, 前回発表した基礎的な研究内容を臨床応用する方法について述べたが, 重要なととは，今後てのシステムを用いて行なうデータの集積とその分析である。今回分 析した症例については, 母音の異聴は純音オージオグラムの形と母音のフォルマント周波 数の関係からある程度説明できるが，子音の異聴については後続母音との関係など種々な 因子が異聴に関与して複雑化しているととが予想され，今後障羖部位も含めた幅広いデ一 夕の集積が必要と思われる。

\section{N PUT}

(1) MONOSYLLABIC CONFUSION STIMULUS

(2) INCORRECT RESPONSES

OBTAINED FROM HEARING IMPAIRED SUBJECTS

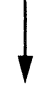

GRAPHIC REPRESENTATION LABELED

"THE SPEECH SOUND CHART OF NORMAL HEARING SUBJECT S ${ }^{2}$

OUTPUT

SUPERIMPOSITION OF STIMULUS-RESPONSE

VECTORS ON THE SPEECH SOUND CHART

LABELED "THE CONFUSION CHART

OF HEARING IMPAIRED SUBJECTS ${ }^{2}$

図 1 マイクロコンピュータシステムの概略

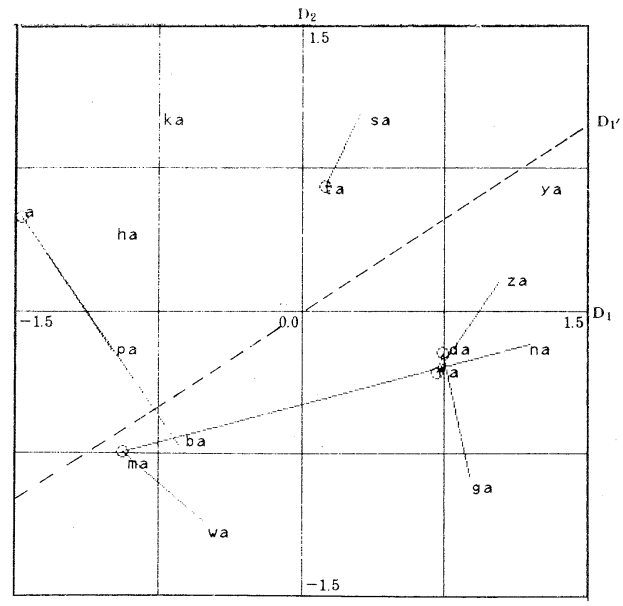

図 3 異聴地図 ( 音節核 $/ \mathrm{a} /$ )

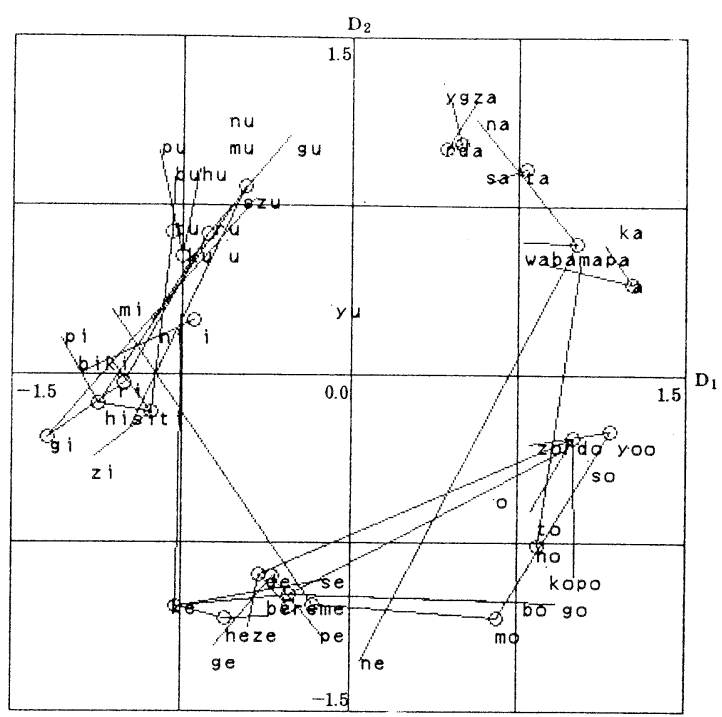

図2 異聴地図 ( 67 語)

(1)カラーディスプレイ上では各文字の正確な座標位置が わかるようになっている。

(2)文字が近接して表示が困難なものは子音部のみ表示さ れている。

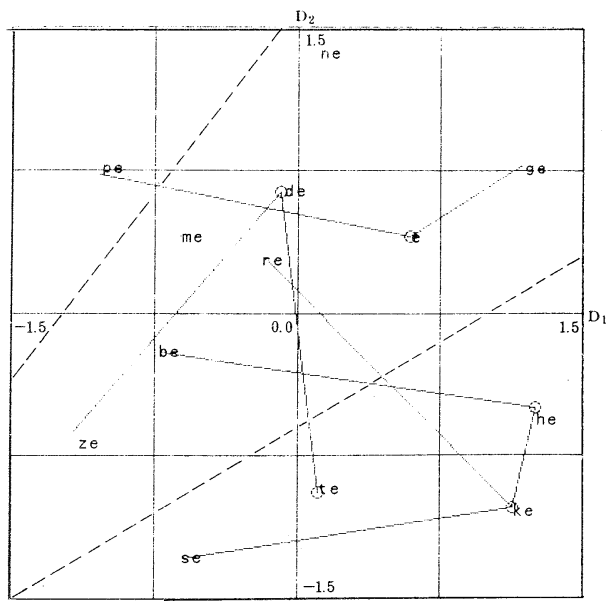

図 4 異聴地図( 音節核 $/ \mathrm{e} /$ ) 